\begin{tabular}{|c|c|c|c|c|c|c|}
\hline \multirow{4}{*}{ Impact Factor: } & ISRA (India) & $=3.117$ & SIS (USA) & $=0.912$ & ICV (Poland) & $=6.630$ \\
\hline & ISI (Dubai, UAE & $=0.829$ & РИНЦ (Russia) & $=0.156$ & PIF (India) & $=1.940$ \\
\hline & GIF (Australia) & $=0.564$ & ESJI (KZ) & $=8.716$ & IBI (India) & $=4.260$ \\
\hline & JIF & $=1.500$ & SJIF (Morocco) & $=5.667$ & OAJI (USA) & $=0.350$ \\
\hline
\end{tabular}

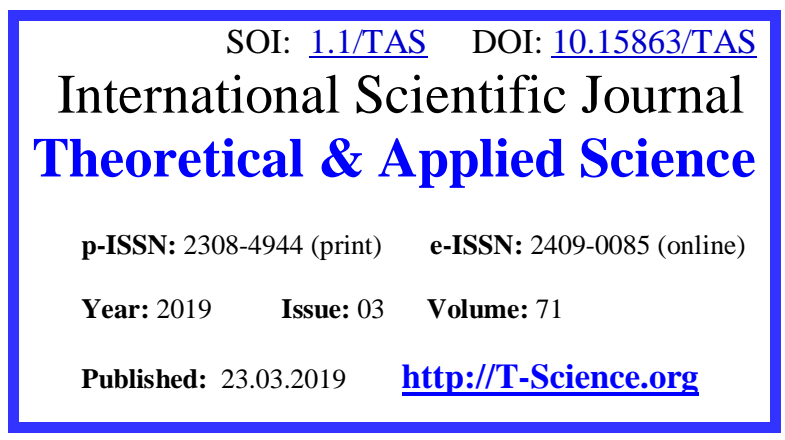

SECTION 7. Mechanics and mechanical engineering.
QR - Issue

QR - Article

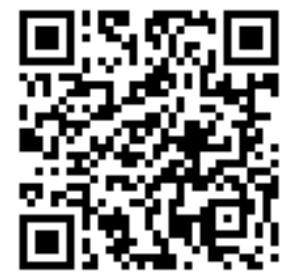

Valery Pavlovich Popov associate Professor, faculty of applied biotechnology and engineering, Orenburg State University sergeigray@gmail.com

Alexander Viktorovich Kolotvin head of the Department, faculty of applied biotechnology and engineering,

Orenburg State University

\title{
UPGRADING AND COST EFFICIENCY OF PROCESSING OF GRAIN RAW MATERIALS AT USE OF CRYOGENIC TECHNOLOGIES
}

\begin{abstract}
Now much attention is paid to a problem of decrease in power consumption of production and upgrading of the received products and, as a result, leading to increase in cost efficiency [1].

By production of forages and feed additives, the extrusive technologies including are more and more actively applied: crushing, mixing and pressing. However in this technology mean the considerable raw and metabolic cost. The rational technology of processing of grain raw materials has to ensure safety of the useful properties of raw materials at each stage of its processing in particular at stages of its crushing and extruding.

In a number of works there are data about use of cryogenic technologies for decrease in power communications in the processed raw materials (preliminary partial destruction of the processed raw materials due to the expansion which is present at it the free moisture upon its transition from liquid state to solid). In particular A.I. Naumov, Egorov G. And, E.D. Kazakov, V.L. Kretovich investigated as temperature influences and also in unison temperature and humidity, and mechanical characteristics of wheat of a grade Tsezium 31 of Altai Krai. Mealy and vitreous fractions of grain were exposed the negative and positive temperatures, and then to a refinement. It was established that low temperatures affect not only covers, but also all volume of grain. If temperature of grain is negative (lower than-10 and below), then the free and bound moisture which always is in a time, capillaries and intercellular spaces of grain, turning into ice and extending, loosens structure of grain and weakens communications between its constituents. As a result of it the resilience of grain to a refinement decreases. Besides, decrease in temperature leads to decrease of a kinetic energy of a headway of molecules of substance, reduces their speed and a free length, grain becomes less viscid and ductile, its brittleness increases.
\end{abstract}

Key words: crushing, power consumption, grain raw materials, technological process, power, formula-feed industry, mathematical model, resource-saving.

Language: English

Citation: Popov, V. P., \& Kolotvin, A. V. (2019). Upgrading and cost efficiency of processing of grain raw materials at use of cryogenic technologies. ISJ Theoretical \& Applied Science, 03 (71), 364-367.

Soi: http://s-o-i.org/1.1/TAS-03-71-26 Doi: crossef https://dx.doi.org/10.15863/TAS.2019.03.71.26

\section{Introduction}

Due to the aforesaid there is a possibility of creation of fundamental bases the krioextrusion of technologies of processing of vegetable raw materials for the purpose of its transformation into food or fodder product. Analogs the offered technology is available in Russia not abroad at present.

Cryogenic processing of grain raw materials allows to keep more biological valuable substances of raw materials (a lignine, cellulose etc) and to prevent formation of undesirable substances (metilanoidin etc), the characteristic of the standard extruded technologies [2-4]. The previous researches developed different technologies of extrusive processing of grain raw materials, however, application of cryogenic influences in technology of processing of grain raw materials wasn't studied. In this regard carrying out researches on development of technology of processing of grain raw materials with 


\begin{tabular}{|c|c|c|c|c|c|c|}
\hline \multirow{4}{*}{ Impact Factor: } & ISRA (India) & $=3.117$ & SIS (USA) & $=0.912$ & ICV (Poland) & $=6.630$ \\
\hline & ISI (Dubai, UAE & $=0.829$ & РИНЦ (Russia & $=0.156$ & PIF (India) & $=1.940$ \\
\hline & GIF (Australia) & $=0.564$ & ESJI (KZ) & $=8.716$ & IBI (India) & $=4.260$ \\
\hline & JIF & $=1.500$ & SJIF (Morocco & $=5.667$ & OAJI (USA) & $=0.350$ \\
\hline
\end{tabular}

application as extrusive and cryogenic technologies is represented relevant.

Object of a research are raw materials of plant origin.

Work purpose: development power - and the resource-saving production technology of forages and feed additives with application of cryogenic impacts on a wastage of agro-industrial complex of the Orenburg region.

The scientific novelty consists in development of technology of receiving qualitative forages and feed additives due to increase in their uniformity and prevention of destruction cellulose-and lignin contained raw materials and also in decrease in specific energy consumptions in the course of their production on the basis of cryoimpacts on a stock. Topical issue for the consumer is the cost efficiency from the introduced technology.

In the offered technology decrease in energy consumption is possible for the account:

- optimization of process of a refinement of a feed stock by selection of the optimum device for a refinement of the frozen raw materials;

- applications of processing of the crushed feed stock chemical reagents [4-6];

- applications of a refinement at underpressure of air [6-10];

- extrusive processing of the prepared mix.

For optimization of operation of a refinement to lines of production of forages and feed additives we carried out comparative tests of several types of reducing machines of small efficiency which are issued the enterprises of Russia.

Their universality and possibility of adaptation to various flow diagrams working both at traditional and on nonconventional raw materials became the main criteria for evaluation of their effectiveness.

The decisive factor in assessment of effectiveness of the crushing device put its mobility in terms of changes in technological process, for example, upon transition from one type of vegetable raw materials to another or change-over of its process parameters.

The production line of extruded compound feeds works as follows.

The initial loose components which are stored in capacities 1 batchers 2 which are established in the bottom of bunkers move in strictly particular portion on installation of shock freezing 4. After shock freezing the loose component moves in a hammer crusher 5 and rotor crusher 6 then the crushed component moves via pipeline 13 on a traveling band 9 for further humidification. As soon as the crushed component which is on conveyor 9 reaches bunkers for storage of liquid components 6 , the drive of the volume batchers 2 established in the bottom of bunkers 6 and at the same time turns on each of liquid components in strictly particular quantity moves in the corresponding nozzles 8 . Then liquid components by means of nozzles 8 are sprayed over a surface of the crushed component, being on an apron 9 . In the course of movement the crushed component mixes up with liquid components. At the same time there is a saturation of the crushed component liquid components. Further the received mix moves in mixer 10 where it actively mixes up. Then the mixed mix comes to the building bag of an extruder 11. The drive turns on and rotating an extruder screw 11 begins to take and move a product which sequentially passes through zones of loading, interfusing, homogenization and dispensing. In process of advance mix mixes up in an interfusing zone, heats up and softened before receiving the homogeneous environment.

At its further advance, there is a consolidation in the compression section, at the expense of the decreasing free volume limited to walls of a housing and a surface of actions and the product is warmed. Further in the metering section there is a transformation of the softened granules into a melt, due to increase of pressure, at the same time the smooth decrease of interturn volume of a screw towards a prematrix zone provides decontamination and gradual increase in pressure of a product. In the metering section mix finally passes from a solid phase into viscoplastic; here melting results from transformation of a mechanical energy of actions of the car to thermal energy and due to internal friction in the product. Extrudate melt pressure in a metering zone reaches desirable value, there is a final fusion of shallow inclusions and the melt, the first in structure and temperature is formed. It allows 11 to have the given, first in section melt temperature of a product for normal work of an extruder. Then it gets to a prematrix zone and is dosed through openings of a matrix of an extruder 11. After a product yield from a matrix as a result of sharp temperature drop and pressure there is a moisture flashing, the energy accumulated by it is released with a speed, approximately equal speed of explosion that leads to formation of a cellular structure and increase in volume of an extrudate.

Then the extrudate moves in a ribbon drier 12 . The conveyor drive with adjustable speed driving of a tape turns on, and at the same time in dryer 12 the heat carrier which penetrates a product layer according to a tape moves, dries up it and is removed from dryer 12.

The line can be follow-up supplied with mixer 14 for interfusing of the crushed components (at inclusion in a compound feed compounding, both pod, and mealy raw materials), we have between pipeline 13 and a traveling band 9 . Use of mixer 14 allows to receive more the first in structure and humidities extrudate compound feed. 


\begin{tabular}{|c|c|c|c|c|c|c|}
\hline \multirow{4}{*}{ Impact Factor: } & ISRA (India) & $=\mathbf{3 . 1 1 7}$ & SIS (USA) & $=0.912$ & ICV (Poland) & $=6.630$ \\
\hline & ISI (Dubai, UAE & $=0.829$ & РИНЦ (Russia & $=0.156$ & PIF (India) & $=1.940$ \\
\hline & GIF (Australia) & $=0.564$ & ESJI (KZ) & $=8.716$ & IBI (India) & $=4.260$ \\
\hline & JIF & $=1.500$ & SJIF (Morocco & $=5.667$ & OAJI (USA) & $=0.350$ \\
\hline
\end{tabular}

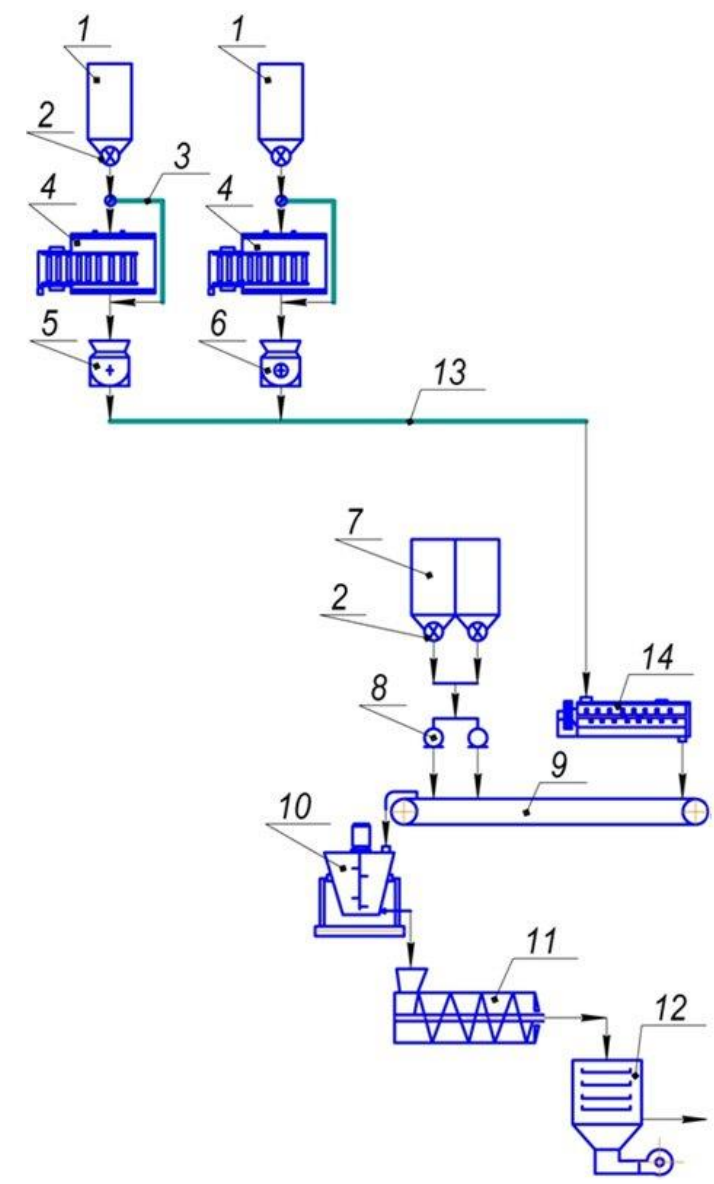

Figure 1 -Production Line of Extruded Compound Feeds.

Power consumption it is observed at the rotor crusher from 0.07 to $0.013 \mathrm{p} / \mathrm{kg}$ when cooling a product up to the temperature of $-120{ }^{\circ} \mathrm{C}$, and efficiency increases from 99 to $145 \mathrm{~kg} / \mathrm{h}$.

Smaller influence of the under temperature on efficiency factors of process of a refinement is observed at a hammer crusher, the value of specific power consumption decreases by $3 \%$, and efficiency increases by $13.2 \%$. In forage production rotor crushers which are widespread in average and shallow farms are most popular. They have small dimensions, low cost at high performance and wide range to adjustment of process parameters [6].

\section{Conclusion}

As showed calculation of cost efficiency at application of shock freezing of raw materials in the offered production line of forages and feed additives at acquisition of the equipment in leasing - the payback period will make 2 years monthly payment of 5035.76 USD, income in 36 months of 0.9 million USD on price situation for September, 2014. Profitability from implementation of new technology will make $32 \%$.

As showed results of researches on optimization of process of a refinement of grain and lininotsellyulozny raw materials by selection of the optimum device for a refinement of the frozen raw materials most efficiently in terms of energy consumption, to carry out a refinement on the rotor crusher (a design of LLC Uralspetsmash) as at almost identical efficiency the rotor crusher less energoyemk

\section{References:}

1. Agote, I., et al. (2011). Rheological study of waste porcelain feedstocks for injection. In the collection: Elsevier Science Publishing Company, Inc. Journal of the european ceramic 


\begin{tabular}{|c|c|c|c|c|c|c|}
\hline \multirow{4}{*}{ Impact Factor: } & ISRA (India) & $=\mathbf{3 . 1 1 7}$ & SIS (USA) & $=0.912$ & ICV (Poland) & $=6.630$ \\
\hline & ISI (Dubai, UAE & $=0.829$ & РИНЦ (Russia & $=0.156$ & PIF (India) & $=1.940$ \\
\hline & GIF (Australia) & $=0.564$ & ESJI (KZ) & $=8.716$ & IBI (India) & $=4.260$ \\
\hline & JIF & $=1.500$ & SJIF (Morocco & $=5.667$ & OAJI (USA) & $=0.350$ \\
\hline
\end{tabular}

society, № 16, 2843-2853, ISSN: 0955-2219, eISSN: 1873-619X.

2. Bulatasov, E., Popov, V., \& Hanin, V. (2017). Determination of deformation characteristics of wood during cutting. University complex as a regional center for education, science and Culture: materials of the All-Russian Scientific and Methodological Conference. (pp.15311535). Orenburg: OOO IPK "University".

3. Bucur, V. (2006). Acoustics of wood. 2nd edition. (p.111). Germany: Springer-Verlag Berlin Heidelberg.

4. Cooper, R. G., \& Wolf, D. (1968). Velocity profiles and pumping capacities for turbine type impellers. Canad J. Chem. Eng., 46, N 2, 94 109.

5. Kobylkin, D. S., Antimonov, S. V., Korotkov, V. G., \& Ganin, E. V. (2008). Crushing under a vacuum in technology of receiving extruded kormosmesy and additives. Storage and processing of agricultural raw materials, No. 6 , 27-29.

6. Kishkilev, S. V., Korotkov, V. G., \& Popov, V. P. (2016). Development of mathematical model of cryocrushing of waste of agro-industrial complex. News of the Orenburg state agricultural university, No. 5, 66-67.

7. Antimonov, S. V., Solov, S. Y., \& Kishkilev, S. V. (2016). ldistost Coefficient as an indicator of quality of process of crushing of grain and the products of his processing which are previously cooled up to the negative temperatures. the
University complex as the regional center of education, science and culture. Materials of the All-Russian scientific and methodical conference (with the international participation). (pp.1041-1043).

8. Timofeeva, D. V., Kishkilev, S. V., Popov, V. P., \& Martynov, N. N. (2016). a transformation Research structurally - mechanical properties and the chemical composition proteinaceous крахмало-клетчаткосодержащего raw materials in the channel of an odnoshnekovy press extruder. the University complex as the regional center of education, science and culture. Materials of the All-Russian scientific and methodical conference (with the international participation). (pp.1007-1014).

9. Korotkov, V. G., Kishkilev, S. V., Martynov, N. N., Martynova, D. V., \& Panov, E. I. (2015). Influence of shock freezing on quality and power consumption of process of crushing of grain raw materials and secondary material resources of food productions by various types of grinders / I/Technical science - from the theory to practice Publishing house: Association of research associates "Siberian academic book" (Novosibirsk). No. 52, 193-202.

10. Antimonov, S. V., Kishkilev, S. V., Solov, S. Y., Korotkov, V. G., \& Popov, V. P. (2013). the Research of process of crushing of grain raw materials after shock freezing. Bakery products, No. 11, 60-62. 